\title{
THE USE OF SMARTPHONE IN MEDICAL PRACTICE
}

\author{
Nada Pop-Jordanova ${ }^{1}$, Mario Loleski $^{2}$, Sofija Loleska ${ }^{3}$ \\ ${ }^{1}$ Macedonian Academy of Sciences and Arts, Skopje, Republic of Macedonia \\ ${ }^{2}$ Ministry of Interior of Republic Macedonia \\ ${ }^{3}$ DFLab, Skopje, Republic of Macedonia
}

Corresponding author: Nada Pop-Jordanova, Macedonian Academy of Sciences and Arts, Bul. Krste Misirkov 2, Skopje, Republic of Macedonia, e-mail: popjordanova.nadica@gmail.com

\begin{abstract}
In this review we present some data about the use of mobile phones in medical practice. The results of over hundred studies cited in PubMed during the last few years have been discussed. The article gives background connected with a project in the Macedonian Academy of Sciences and Arts referring to a personal mobile phone application named "Neurogame" which is currently constructed to evaluate motor skills related to attention and concentration in different samples of people.
\end{abstract}

Keywords: mobile phones, medicine, information sciences

\section{INTRODUCTION}

We live in an age where many technologies have transformed our everyday lives and commerce (e.g., the worldwide web, tablets, cell phones, wifi, the Cloud, Skype, Amazon, Expedia, Google). Digital technology has rapidly and dramatically shifted humans' interaction with the world and presents an enormous opportunity to develop, test, and widely disseminate effective health behavior change interventions. Precisely, developing effective digital interventions to change health behavior has been a challenging goal for both, academics and industry.

Nowadays prevalence of mobile phones users is especially high and is exponentially increasing in many countries, including Macedonia. Our previous study showed that even $96,26 \%$ of all school children use their own mobile phones. We have obtained results re- garding the presence of some hypersensitive reactions, but other serious negative effects from electromagnetic fields induced by mobile phones were not confirmed [Pop-Jordanova, 2006, 2011, 2012, 2014, 2015].

The prospect of modifying lifestyle behaviors, such as diet, physical activity, smoking, and sleep, in order to improve health outcomes has increasingly driven efforts. The use of mobile phones in medical practice is based generally in this direction, with a behavioral theory as a starting point.

Behavioral theory is widely acknowledged to be critical to the development of interventions directed to change health behavior. Behaviorism is known as a learning theory that only focuses on objectively observable behaviors and discounts any independent activities of the mind. In this context, behavior the- 
orists define that "learning is nothing more than the acquisition of new behavior based on environmental conditions" [Mummah SA et al.; 2016].

In PubMed we can find many articles devoted to the use of mobile phone in different medical branches. In this review paper, the main purpose is to explain some of them in brief.

\section{METHOD AND MATERIAL}

The PubMed publications from the last few years are the main source of this review. Key words used are: mobile phones, medicine and information science. More than hundred articles
Because cardiology is the medical branch most frequently related to high morbidity, mortality and cost, mobile phones, due to their audio processing capabilities, have the potential to facilitate the diagnosis of heart disease through automated auscultation [Dang S. et al.; 2017]. Managing chronic heart diseases requires considerable self-management skills and self-efficacy. In the cited study, it was shown that a mobile phone-based disease management program may help improve self-care efficacy and quality of life in patients with chronic heart failure. Figure 1 shows the simple technique of monitoring heart function by use of mobile phone devices.

The field of arrhythmia is additionally well known and its monitoring is changing frequently.
4. ECG with wireless communication

\section{Flexible conductive fibers}

2. Electrode cable

1. Textile dry dielectric
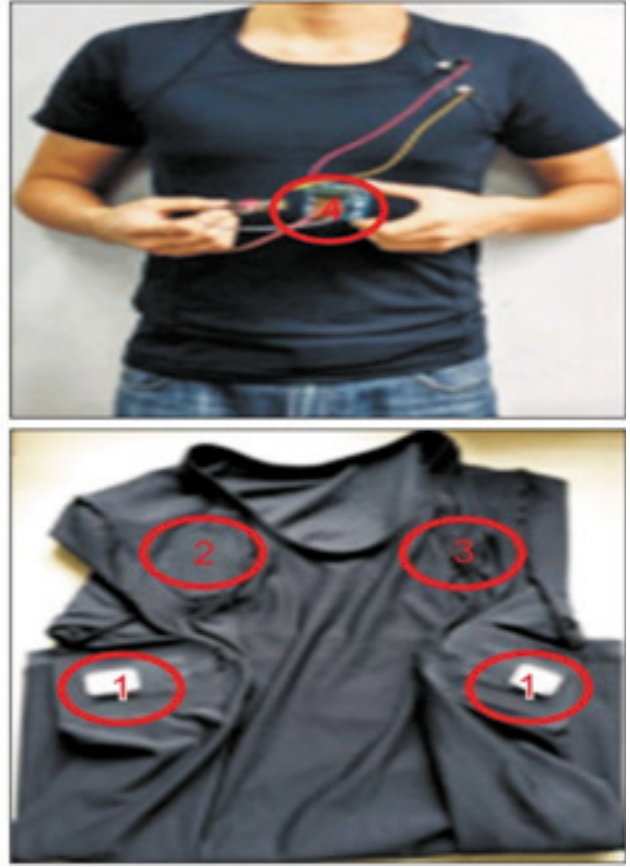

Figure 1. Portable ECG connected with mobile phone

appeared. In this review only articles related to mobile phones and their application in medical settings are selected.

\section{RESULTS}

Smartphones are ubiquitous, but it is still unknown what physiological functions can be monitored at clinical quality. Hereiafter, only more attractive and practical uses are cited.
The rapid advent of technology in combination with marked improvements in cellular communication and an increased desire by patients to be actively engaged in their care has ushered in a new era of clinical care. Smartphone-based electrocardiographic and cardiac implantable electronic device monitoring was used by Mittal S. (2017) and it has shown that this technique allow the patient to assume a greater stake in their own care.

It is known that pulmonary function is a standard measure of health status for cardiopulmonary patients. Cheng Q. et al.; (2017) has shown 
that phone sensors can measure walking patterns. They have shown that improved classification models can accurately measure pulmonary function, where sensor data from carried phones are the sole inputs. Obtained results for pulmonary function are similar to those measured by spirometer.

Adherence to antihypertensive medication remains a key modifiable factor in the management of hypertension. Peacock E. and Krousel-Wood M. (2017) highlighted that promising strategies to improve antihypertensive medication adherence and blood pressure control include regimen simplification, reduction of out-of-pocket costs, use of allied health professionals for intervention delivery, and self-monitoring of blood pressure by technology-mediated interventions, especially by use of mobile phones.

The requirement for self-health monitoring and preventive medicine is increasing due to the projected dramatic increase in the number of elderly people until 2020. Developed technologies are truly able to reduce the overall costs for prevention and monitoring. This is possible by constantly monitoring health indicators in various areas, and in particular, wearable devices are considered to perform this task. These wearable devices and mobile apps now have been integrated with telemedicine and telehealth efficiently. In one study by Richardson JE. et al. (2017), the aim was to determine the role that smartphones may play in supporting older adults with chronic noncancer pain $(\mathrm{CNCP})$ in order to improve pain management in this expanding population. The conclusion of the study was that smartphones that focus on supporting medication management, enhancement of communication with providers, and facilitating connectedness within social networks to reduce feelings of isolation may help improve $\mathrm{CNCP}$ outcomes in older adults.

Another field in medicine, related especially to woman with osteoporosis is also connected to the application of mobile phones. Interventions to prevent osteoporosis by increasing dairy intake or physical activity in young women have been limited to increasing knowledge and awareness of osteoporosis. Self-monitoring using mobile devices in behavioral interventions has yielded significant and positive outcomes. In a recent preliminary study by Tay I. et al.; (2017) acceptable use of Calci-app was demonstrated in order to self-monitor calcium consumption.

Digital mental health tools have tended to use psychoeducational strategies based on treat- ment orientations developed and validated outside digital health. The group of Mohr DC. et al. (2017) developed a suite of apps for depression and anxiety called "IntelliCare", with a focused goal and interactional style. "IntelliCare" apps prioritize interactive skills training over education and are designed for frequent but short interactions. The "IntelliCare" system is elemental, allowing individual apps to be used upon their effectiveness and utility, and it is eclectic, viewing treatment strategies as elements that can be applied as needed rather than adhering to a singular, overarching, theoretical model.

In the same context, Hung S. et al. (2016) published results of a smartphone application, iHOPE, used to perform daily ecological momentary assessment of depression, anxiety, sleep and cognitive performance. The study provides initial evidence for the feasibility of smartphone-based ecological momentary assessment in Chinese patients with depression.

Hypothermia is an independent risk factor for neonatal mortality and morbidity. To prevent it, an automated monitoring system is required. In this context an automated neonatal health monitoring system is designed using sensor mobile cloudcomputing (SMCC). De D. et al. (2016) inovates this system with a temperature sensor, acceleration sensor and heart rate measurement sensor used to monitor body temperature, acceleration due to body movement and the heart rate of neonates. The sensor data are stored inside the cloud. The health person continuously monitors and accesses these data through the mobile device using an android application for neonatal monitoring. When an abnormal situation arises, an alert is generated in the mobile device of the health person. By alerting health professional using such an automated system, early care is provided to the affected babies and the probability of recovery is increased.

Opposite to the usefulness, portable mobile and media devices as a ubiquitous part of children's lives may affect their sleep duration and quality. Bedtime access to and use of a media device were significantly associated with inadequate sleep quantity, poor sleep quality, and excessive daytime sleepiness [Carter B et al 2016].

Diabetes Mellitus is a chronic disease that is considered a global public health problem. Education and self-monitoring by diabetic patients help in the process of optimizing and enabling satisfactory metabolic control thus improving man- 
agement and reducing morbidity and mortality. The use of apps by diabetic patients could help improve the control of HbAlc. In addition, the apps seem to strengthen the perception of self-care by contributing to better information and health education to patients. Patients also become more self-confident to deal with their diabetes, mainly by reducing their fear of not knowing how to deal with potential hypoglycemic episodes that may occur [Bonoto BC. et al; 2017].

Shibuta T. et al. (2017) examined the prevalence of the willingness of patients with diabetes to use a self-management tool based on information and communication technology (ICT) such as personal computers, smartphones, and mobile phones, and to examine the patient characteristics associated with that willingness. The results of the study showed that approximately half of the evaluated patients showed interest in using an ICT-based self-management tool. Willing patients may expect ICT-based self-management tools to complement outpatient visits and to make self-management easier. Starting with patients who display the willingness factors might optimize programs based on such tools. music-contingent stepping-in-place (SIP) training program to improve step automaticity during dual-tasking (DT). Wearable device technology can be used to enable musically-contingent SIP training to increase motor automaticity for people living with Parkinson's disease. The training approach described in the mentioned study can be implemented at home to meet the growing demand for self-management of symptoms by patients themselves. Figure 2 shows how steps of patients changes when music is included by mobile phones. During the training, if step height (black trace) is above the threshold (red dotted line), music will play (green regions), while if step height is below the threshold, music does not play. This allows participants to use real-time step measurements and analytics that provide biofeedback to help self-motivation and self-activation reward networks with training.

Swendeman D. et al. (2017) used mobile phone in the treatment of HIV patients. Potential benefits of this techniques include: 1) enhancement ofpatient engagement, motivation, adherence, and self-management; and 2) improvement in provider-patient relationships and healthcare

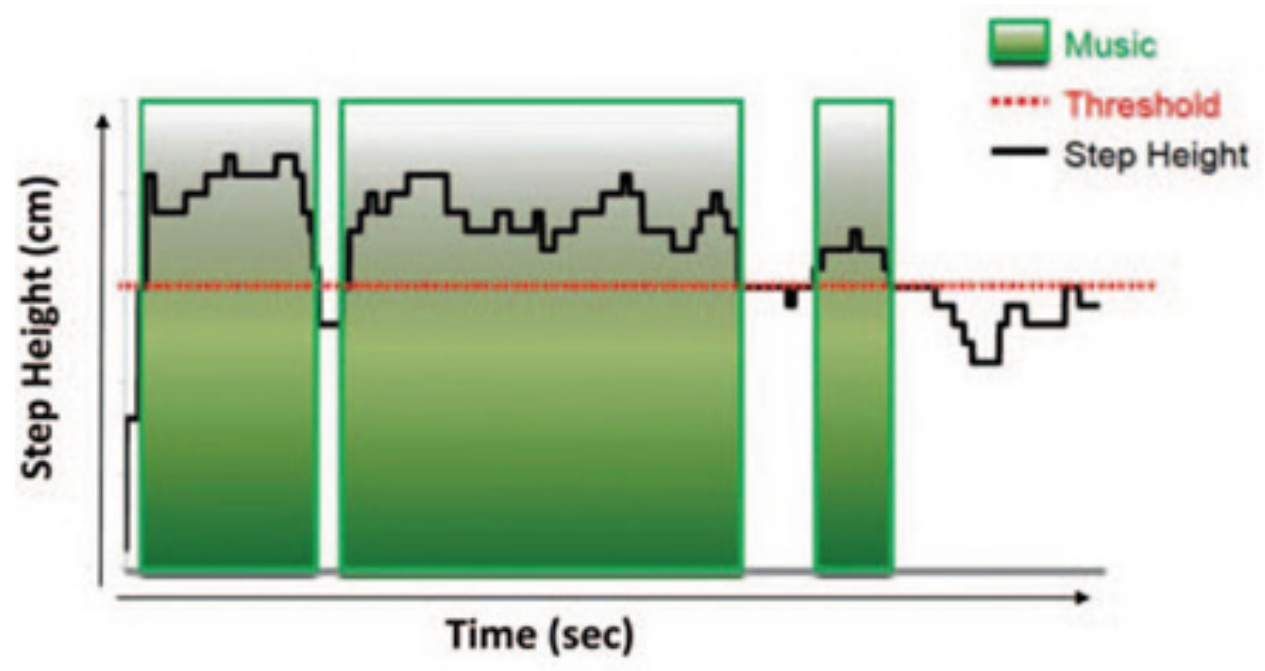

Figure 2. Steps height of patients changes depending on music included in mobile phones

Deficits in motor movement automaticity in Parkinson's disease, especially during multitasking, are early and consistent hallmarks of cognitive function decline, which increases fall risk and reduces quality of life. The study of Chomiak T. et al. (2017) aimed to test the feasibility and potential efficacy of a wearable sensor-enabled technological platform designed for an in-home providers care coordination. Newly diagnosed and patients with co-morbidities were the highest priorities for mobile application support. Facilitators included universal mobile phone ownership and use of smartphones or text messaging. However, some barriers related to this kind of techniques has been observed. The patient-level barriers included concerns about low motivation and financial instability for consistent use by some 
patients. Organizational barriers, cited primarily by physicians, included concerns about privacy protections, easy dashboard access, non-integrated electronic records, and competing burdens in limited appointment times. Psychosocial services providers were most supportive of the proposed mobile tools.

In the field of rheumatology digital assessment and graphical feedback of patient-reported outcome measures such as the Health Assessment Questionnaire (HAQ) could increase empowerment and involvement of patients in their own care process. The App ecosystem is an example of how digital assessment using mobile devices can be integrated into existing hospital IT infrastructure [Catarinella FS. et al.; 2016].

In pediatric practice, the new multidimensional questionnaires for juvenile idiopathic arthritis, juvenile dermatomyositis, and juvenile autoinflammatory diseases integrate all major parents and child-reported outcomes used in these diseases into a single tool, and provide an effective guide to manage, document change in health, assess effectiveness of therapeutic interventions, and verify the parent and child satisfaction with illness outcome. Development of electronic versions of questionnaires that permit their completion through smartphones or touch-screen devices will revolutionise information collection from parents and children, foster the regular collection of parents and child-reported outcomes in routine care, and ultimately improve the quality of self-reported health data, and patient outcomes [Consolaro A. et al.; 2016].

For pediatricians, activity behaviours (physical activity, sedentary time and screen time) have been directly linked to health outcomes in childhood. It was proven that children with less electronic devices, particularly in their bedrooms, participated in less screen time, regardless of socioeconomic status. Socioeconomic disparities were identified in children's moderate-to-vigorous physical activity; however socioeconomic status was inconsistently related to possession of active play equipment. Home active play equipment was therefore not a clear contributor to the socioeconomic gradients in Australian children's moderate-to-vigorous physical activity [Dumuid D. et al.; 2016].

When school districts choose not to participate in adolescent health behavior surveys, tracking adolescent health indicators can be challenging. Brooks MJ. et al. (2017) conducted a count- ywide youth behavior survey outside the school system. Their purpose was to describe alternative methods used for gathering these data reliably and ethically. An anonymous phone-based survey used computer-assisted telephone interviewing with a live interviewer in conjunction with an interactive voice response system to survey youth via random digit dialing of landlines and cell phones. These techniques can provide a basis to collect data that may help direct resources and policies relevant to needs of local youth.

Triantafyllidis AK. et al. (2017) proposed a framework for designing sensor-based health monitoring systems aiming to provide extensible and usable monitoring services in the scope of pervasive patient care. Portable or wearable sensing devices measure the patient's physiological parameters, a smart mobile device collects and analyses the sensor data, a medical center system receives notifications on the detected health condition, and a health professional platform is used by formal caregivers in order to review the patient condition and configure monitoring schemas. Preliminary usability results show the applicability, usefulness and virtue of this approach.

In the 2016, the group of Aronoff-Spencer E. described the detection of Hepatitis C core antibody by dual-affinity yeast chimera and smartphone-based electrochemical sensing. The electrochemical format and a custom, low-cost smartphone-based potentiostat yielded comparable results to assays performed on a state-of-theart electrochemical workstation.

Figure 3 shows some available wearable devices which can be connected with mobile phones and are used today for selfhealth monitoring [Haghi M.et al.; 2017]. The approach pioneered as Psychoinformatics is described as an emerging discipline that uses tools and techniques from the computer and information sciences to improve the acquisition, organization, and synthesis of psychological data. Besides experiments and questionnaires, it establishes a third fundamental research technique: the observation of human-device interaction on a very large scale. It allows psychologists to analyze variables such as personality traits, aptitudes, and cognitive functions, as well as behavior. Most importantly, it avoids most sources of bias, because the behavior of interest is directly recorded [Montag C. et al.; 2016].

Many adolescents and adults do not seek treatment for mental health symptoms. Smartphone applications (apps) may assist individuals 
with mental health concerns in alleviating symptoms or increasing understanding. The most common supported purpose for the apps was symptom relief and general mental health education. The most frequently mentioned approaches to improving mental health were those that may benefit only milder symptoms such as relaxation. Most app descriptions did not include information to substantiate stated effectiveness of the application and had no mention of privacy or security [Radovic A. et al. 2016].

The study of Mohr DC. et al. (2017) supports the so cold "IntelliCare framework" in providing a suite of skills-focused apps that can be used frequently and briefly to reduce symptoms of depression and anxiety. The IntelliCare system is elemental, allowing individual apps to be used regarding their effectiveness and utility, and it is eclectic, viewing treatment strategies as elements that can be applied as needed rather than adhering to a singular, overarching, theoretical model.

Mobile phone text messages (short message service, SMS) are used pervasively as a form of communication. Almost $100 \%$ of the population mental health situations, notably substance abuse, schizophrenia, and affective disorders. Text messages can be used in four ways, i.e. by usage of: reminders, information, supportive messages, and self-monitoring procedures. Applications are sometimes combined. Overall, a positive attitude toward text messages has been reported. Doctors reported improved treatment adherence and symptom surveillance. Other positive points included an increase in appointment attendance and satisfaction in management and health care services. Insight into message content, preventative strategies, and innovative approaches derived from the mental health field may be applicable in other medical specialties [Berrouiguet S. et al; 2016].

Telemedicine using cellular phones allows real-time consultation of burn patients seen at distant hospitals. Two researchers, den Hollander D. and Mars M. (2017) required completion of a proforma, to ensure collection of the following information: demographics, mechanism of injury, vital signs, relevant laboratory data, management at the referring hospital and advice given by the burn team. They have concluded that telemedicine

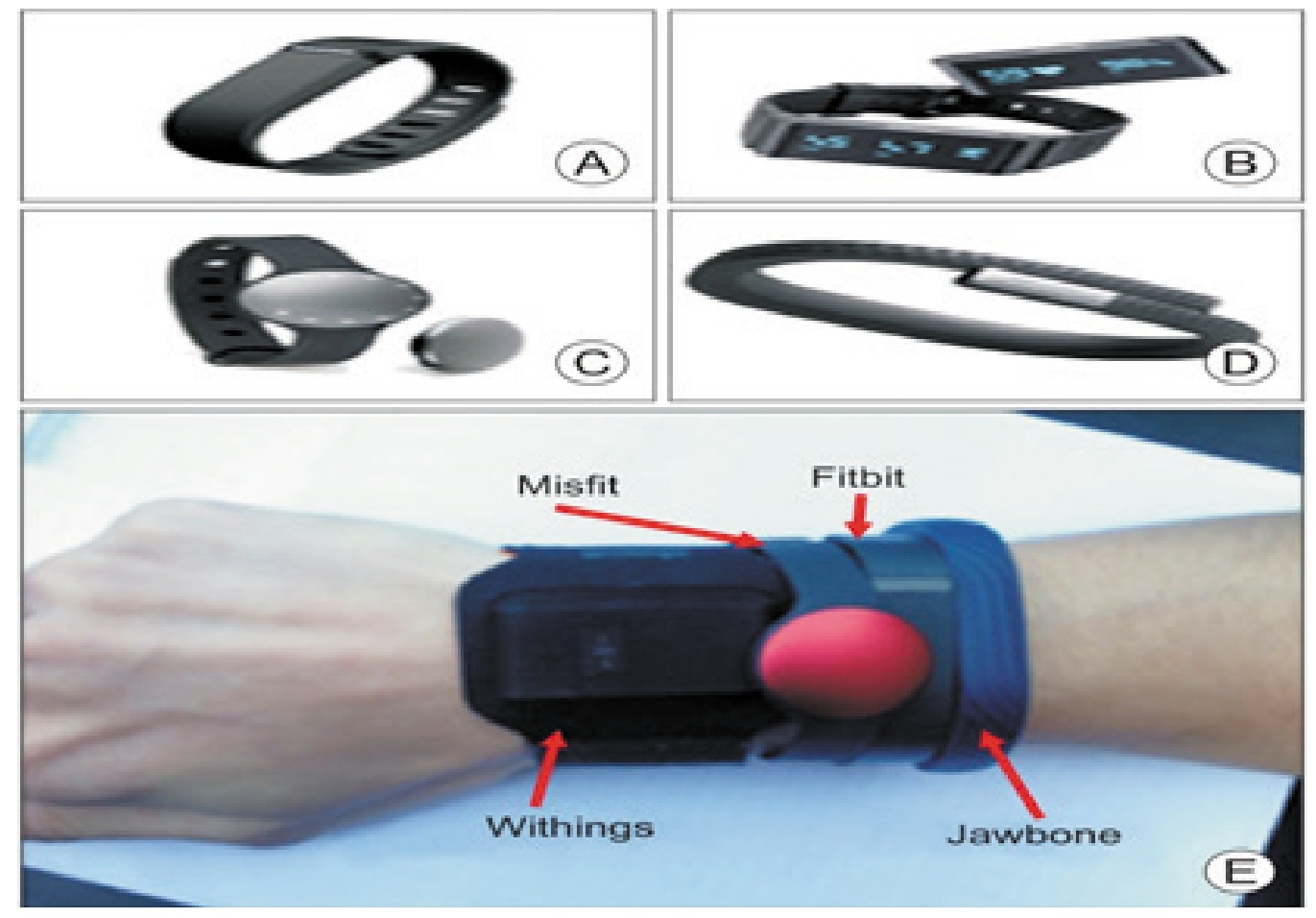

Figure 3. Wearable devices for self-health monitoring

uses text messaging worldwide and this technology is being suggested as a promising tool in psychiatry. Text messages can be sent either from a classic mobile phone or a web-based application. Text messaging was used in a wide range of consultations using a cellular phone significantly change referral pathways in burns.

The goal of the study by Kukolja Taradi S. et al. (2016) was to determine whether an active learning/teaching strategy facilitated with mo- 
bile technologies can improve students' levels of memory retention of key physiological concepts. Using their cell phones, students answered the same questions and the results were compared with a group without a mobile phone use. It was shown that mobile phone users were three time better in memory retention in reference to the key physiological concepts.

Suicide is a leading cause of death globally, and there has been a rapid growth in the use of new technologies such as mobile health applications (apps) to help identify and support those at risk. Larsen ME. et al.(2016) identified apps referring to suicide or deliberate self-harm on the Android and iOS app stores. App features were labelled using a coding scheme that reflected the broad range of evidence-based medical and population-based suicide prevention interventions. It was shown that the best-practice for suicide prevention was based upon a World Health Organization report and supplemented by other reviews of the literature. Despite the number of apps available, and their varied purposes, there is accentuated a clear need to develop useful, pragmatic, and multifaceted mobile resources for this population. Clinicians should vary in recommending apps, especially as potentially harmful content can be presented as helpful.

In a randomized controlled pilot study in overweight adults Mummah SA. et al. (2016) described a mobile app intervention which may be useful for increasing vegetable consumption among overweight adults. For this reason they patented a tool named Vegethon. Given the improved health outcomes associated with increases in vegetable consumption, these findings indicate the need for larger, longer-term evaluations of Vegethon and similar technologies among overweight adults and other suitable target groups.

Consumer sleep tracking devices such as fitness trackers and smartphone apps have become increasingly popular. These devices claim to measure the sleep duration of their users and in some cases purport to measure sleep quality and awaken users from light sleep, potentially improving overall sleep. The growing literature comparing these devices against polysomnography/actigraphy shows that they tend to underestimate sleep disruptions and overestimate total sleep times and sleep efficiency in normal subjects. Most of these devices appear to utilize data generated from inbuilt accelerometers to determine sleep parame- ters but the exact mechanisms and algorithms are proprietary [Kolla BP. et al. 2016].

\section{CONCLUSIONS}

- In conclusion, we can point out that today's use of mobile phones is much larger than to be only communication devices.

- Mobile phones can be very useful tools in medical practice. We showed using published articles in PubMed that mobile phones are used in cardiology, pulmology, endocrine diseases especially diabetes mellitus, different mental health conditions, in pediatrics, geriatrics etc.

- Information technology has a large implications in detection, assessment, and therapy of different medical conditions.

\section{REFERENCES}

1. Aronoff-Spencer E, Venkatesh AG, Sun A, Brickner H, Looney D, Hall DA. Detection of Hepatitis $\mathrm{C}$ core antibody by dual-affinity yeast chimera and smartphone-based electrochemical sensing. Biosens Bioelectron. 2016 Dec 15;86:690-6. doi: 10.1016/j.bios.2016.07.023. Epub 2016 Jul 9.

2. Berrouiguet S, Baca-García E, Brandt S, Walter M, Courtet P. Fundamentals for Future Mobile-Health (mHealth): A Systematic Review of Mobile Phone and Web-Based Text Messaging in Mental Health. J Med Internet Res. 2016 Jun 10;18(6):e135. doi: 10.2196/jmir.5066.

3. Bonoto BC, de Araújo VE, Godói IP, de Lemos LL, Godman B, Bennie M, Diniz LM, Junior AA. Efficacy of Mobile Apps to Support the Care of Patients With Diabetes Mellitus: A Systematic Review and Meta-Analysis of Randomized Controlled Trials. JMIR Mhealth Uhealth. 2017 Mar 1;5(3):e4. doi: 10.2196/mhealth.6309.

4. Brooks MJ, Bear T, Hacker K, Ricci EM, Foulds A, Anderson H, Raible C, Miller E. An Alternative Technique for Youth Risk Surveillance Outside of the School System. J Adolesc Health. 2017 Jan;60(1):72-78. doi: 10.1016/j.jadohealth.2016.08.014. Epub 2016 Oct 25.

5. Cheng Q, Juen J, Bellam S, Fulara N, Close D, Silverstein JC, Schatz B. Classification Models for Pulmonary Function using Motion Analysis from 
Phone Sensors. AMIAAnnu Symp Proc. 2017 Feb 10;2016:401-410. eCollection 2016.

6. Consolaro A, Morgan EM, Giancane G, Rosina S, Lanni S, Ravelli A. Information technology in paediatric rheumatology. Clin Exp Rheumatol. 2016 Sep-Oct;34(5 Suppl 101):S11-S16. Epub 2016 Oct 18

7. Catarinella FS, Bos WH. Digital health assessment in rheumatology: current and future possibilities. Clin Exp Rheumatol. 2016 Sep-Oct;34(5 Suppl 101):S2-S4. Epub 2016 Oct 18.

8. Carter B, Rees P, Hale L, Bhattacharjee D, Paradkar MS. Association Between Portable ScreenBased Media Device Access or Use and Sleep Outcomes: A Systematic Review and Meta-analysis. JAMA Pediatr. 2016 Dec 1;170(12):1202-1208. doi: 10.1001/jamapediatrics.2016.2341.

9. Chomiak T, Watts A, Meyer N, Pereira FV, Hu B. A training approach to improve stepping automaticity while dual-tasking in Parkinson's disease: A prospective pilot study. Medicine (Baltimore). 2017 Feb;96(5):e5934. doi: 10.1097/ MD.0000000000005934.

10. Dang S, Karanam C, Gómez-Marín O. Outcomes of a Mobile Phone Intervention for Heart Failure in a Minority County Hospital Population. Telemed J E Health. 2017 Jan 4. doi: 10.1089/tmj.2016.0211. [Epub ahead of print]

11. De D, Mukherjee A, Sau A, Bhakta I.Design of smart neonatal health monitoring system using SMCC. Healthc Technol Lett. 2016 Nov 2;4(1):1319. doi: 10.1049/htl.2016.0054. eCollection 2017.

12. den Hollander D, Mars M. Smart phones make smart referrals: The use of mobile phone technology in burn care - A retrospective case series. Burns. 2017 Feb;43(1):190-194. doi: 10.1016/j. burns.2016.07.015. Epub 2016 Aug 27.

13. Dumuid D, Olds TS, Lewis LK, Maher C. Does home equipment contribute to socioeconomic gradients in Australian children's physical activity, sedentary time and screen time? BMC Public Health. 2016 Aug 5;16:736. doi: 10.1186/s12889016-3419-9.

14. Haghi M, Thurow K, Stoll R.Wearable Devices in Medical Internet of Things: Scientific Research and Commercially Available Devices. Healthc
Inform Res. 2017 Jan;23(1):4-15. doi: 10.4258/ hir.2017.23.1.4. Epub 2017 Jan 31.

15. Hung S, Li MS, Chen YL, Chiang JH, Chen YY, Hung GC. Smartphone-based ecological momentary assessment for Chinese patients with depression: An exploratory study in Taiwan. Asian J Psychiatr. 2016 Oct;23:131-136. doi: 10.1016/j. ajp.2016.08.003. Epub 2016 Aug 8.

16. John ME, Samson-Akpan PE, Etowa JB, Akpabio II, John EE. Enhancing self-care, adjustment and engagement through mobile phones in youth with HIV. Int Nurs Rev. 2016 Dec;63(4):555-561. doi: 10.1111/inr.12313. Epub 2016 Sep 21.

17. Kolla BP, Mansukhani S, Mansukhani MP. Consumer sleep tracking devices: a review of mechanisms, validity and utility. Expert Rev Med Devices. 2016 May;13(5):497-506. doi: 10.1586/17434440.2016.1171708. Epub 2016 Apr 18.

18. Kukolja Taradi S, Taradi M. Making physiology learning memorable: a mobile phone-assisted case-based instructional strategy. Adv Physiol Educ. 2016 Sep;40(3):383-7. doi: 10.1152/advan.00187.2015.

19. Larsen ME, Nicholas J, Christensen H.A Systematic Assessment of Smartphone Tools for Suicide Prevention. PLoS One. 2016 Apr 13;11(4):e0152285. doi: 10.1371 /journal.pone.0152285. eCollection 2016.

20. Mittal S. Smartphone-Based Electrocardiographic and Cardiac Implantable Electronic Device Monitoring. Cardiol Rev. 2017 Jan/Feb;25(1):12-16.

21. Montag C, Duke E, Markowetz A. Toward Psychoinformatics: Computer Science Meets Psychology. Comput Math Methods Med. 2016; 2016: 2983685

22. Mohr DC, Tomasino KN, Lattie EG, Palac HL, Kwasny MJ, Weingardt K, Karr CJ, Kaiser SM, Rossom RC, Bardsley LR, Caccamo L, StilesShields C, Schueller SM. IntelliCare: An Eclectic, Skills-Based App Suite for the Treatment of Depression and Anxiety. J Med Internet Res. 2017 Jan 5;19(1):e10. doi: 10.2196/jmir.6645.

23. Mummah SA, Mathur M, King AC, Gardner CD, Sutton S. Mobile Technology for Vegetable Consumption: A Randomized Controlled Pilot Study in 
Overweight Adults. JMIR Mhealth Uhealth. 2016 May 18;4(2):e51. doi: 10.2196/mhealth.5146.

24. Peacock E, Krousel-Wood M. Adherence to Antihypertensive Therapy. Med Clin North Am. 2017 Jan;101(1):229-245. doi: 10.1016/j. mena.2016.08.005.

25. Pop-Jordanova, Мобилните телефони и здравјето, Образовни рефлекси, 2006; 3: 76-78

26. Pop-Jordanov J., Pop-Jordanova N. Mobile phones, E E G and Mental Activity, WebmedCentral BRAIN [electronic source], published on: 30.01.2011, article (URL): https://www.webmedcentral.com/wmcpdf/

27. Article WMC001370.pdf, 2011; 2 (1): WMC001493 (1-7)

28. Pop-Jordanova N., Pop-Jordanova S. Health symptoms caused by electromagnetic radiation, Physioacta, 2012; 6 (2): 33-45

29. Pop-Jordanova N., Loleska S. Hypersensitive reactions in humans due to electromagn etic radiation, Book of digests: 5th Symposium on Applied Electromagnetics - SAEM'2014, Skopje, Macedonia, June 8-11, 2014, eds. L. Petkovska, G. Cvetkovski, Faculty of Electrical Engineering and Information Technologies, Skopje, 2014: 1-2

30. Pop-Jordanova N., Loleska S. Some negative effects of mobile phone's use, International Journal of Scientific Engineering and Applied Science (IJSEAS), 2015; 2 (6): 2395-3470

31. Radovic A, Vona PL, Santostefano AM, Ciaravino S, Miller E, Stein BD. Smartphone Applications for Mental Health. Cyberpsychol Behav
Soc Netw. 2016 Jul;19(7):465-70. doi: 10.1089/ cyber.2015.0619.

32. Richardson JE, Lee JI, Nirenberg A, Reid MC. The Potential Role for Smartphones Among Older Adults with Chronic Noncancer Pain: A Qualitative Study. Pain Med. 2017 Jan 20. pii: pnw284. doi: $10.1093 / \mathrm{pm} / \mathrm{pnw} 284$. [Epub ahead of print]

33. Swendeman D, Farmer S, Mindry D, Lee SJ, Medich M. HIV Care Providers' Attitudes regarding Mobile Phone Applications and Web-Based Dashboards to support Patient Self-Management and Care Coordination: Results from a Qualitative Feasibility Study. J HIV AIDS. 2016 Oct;2(4). doi: 10.16966/2380-5536.127. Epub 2016 Jun 21.

34. Shibuta T, Waki K, Tomizawa N, Igarashi A, Yamamoto-Mitani N, Yamaguchi S, Fujita H, Kimura S, Fujiu K, Waki H, Izumida Y, Sasako T, Kobayashi M, Suzuki R, Yamauchi T, Kadowaki T, Ohe K. Willingness of patients with diabetes to use an ICT-based self-management tool: a cross-sectional study. BMJ Open Diabetes Res Care. 2017 Feb 7;5(1):e000322. doi: 10.1136/ bmjdrc-2016-000322. eCollection 2017.

35. Tay I, Garland S, Gorelik A, Wark JD.Development and Testing of a Mobile Phone App for Self-Monitoring of Calcium Intake in Young Women. JMIR Mhealth Uhealth. 2017 Mar 7;5(3):e27. doi: 10.2196/mhealth.5717.

36. Triantafyllidis AK, Koutkias VG, Chouvarda I, Adami I, Kouroubali A, Maglaveras N. Framework of sensor-based monitoring for pervasive patient care. Healthc Technol Lett. 2016 Aug 12;3(3):153-158. eCollection 2016. 


\section{Резиме}

КОРИСТЕЊЕ НА МОБИЛНИТЕ ТЕЛЕФОНИ

ВО МЕДИЦИНСКАТА ПРАКТІКА

(РЕВИЈАЛЕН ТРУД)

\section{Нада Поп-Јорданова ${ }^{1}$, Марио Лолески ${ }^{2}$ Софија Лолеска ${ }^{3}$}

${ }^{1}$ Македонска академија на науките и уметностите, Скопје, Република Македонија

${ }^{2}$ Министерство за внатрешни работи на Република Македонија

3 ДФЛаб, Скопје, Република Македонија

Во овој ревијален труд презентирани се податоци за користењето на мобилните телефони во медицинската практика. Дискутирани се резултатите од стотина студии објавени на ПубМед во последниве години. Трудот беше неопходен како основа за нашиот проект финансиран од МАНУ, а посветен на сопствениот мобилен систем наречен „Невроигра“, конструиран за евалуирање на моторните вештини, поврзани со вниманието и концентрацијата кај различни примероци од популацијата.

Клучни зборови: мобилни телефони, медицина, информатичка наука 